\title{
Risk Analysis of Energy Balance in the Context of Polish Mining Production
}

\author{
Izabela Jonek-Kowalska
}

Silesian University of Technology, Faculty of Organization and Management, Zabrze, Poland

izabela.jonek-kowalska@polsl.pl

Received date:29 August 2017; Accepted date:2 December 2017; Published date: 12 September 2019

Academic Editor: Carmen Nadia Ciocoiu

Copyright (C) 2019. Izabela Jonek-Kowalska. Distributed under Creative Commons CC-BY 4.0

\begin{abstract}
Maintaining the energy security is one of the key economic priorities, in which long-term monitoring and shaping of the energy structure takes a leading role. Such monitoring should be accompanied by forecasting the energy needs of the economy and determining the sources of their coverage. Bearing in mind the above circumstances, the main aim of this article is to carry out a long-term analysis of Poland's energy balance in the context of current and future conditions of the European climate policy and the sources of risk generated by changes observed for Polish mining production. The research period covers the years 1965-2015, and the research was conducted using basic statistical risk measures, including structural ratios, trend analyzes, standard deviations and coefficients of variation, additionally using a risk checklist based on literature studies on European legal and economic conditions in the field of energy and environmental protection policy. Undoubtedly, it can be stated on the basis of the conducted research that the changes in Poland's energy balance, caused largely by the European Union's anti-coal policy, pose a serious threat to hard coal extraction and consumption, however, due to their evolutionary and slow nature, they are not a source of risk that would contribute to immediate collapse of demand and complete liquidation of mining production.
\end{abstract}

Keywords: energy balance, mining production, energy risk, hard coal mining industry in Poland.

\section{Introduction}

The determinants of much diversified character play a vital role in planning the coverage of electricity demand. In the process of their identification, it is helpful to analyze historical trends in terms of sources of covering the current demand and changes taking place in the energy balance, as well as in-depth studies on the current and planned implementation of provisions of the regional and local energy policy. At the same time, it is worth emphasizing that these changes are usually very slow due to the time-consuming and capital-intensive nature of the 
modernization of energy infrastructure, therefore the process of adapting the energy to the new energy and environmental requirements usually covers from a dozen or so to a few dozen years (Turek, 2015). Consequently, the effective and efficient planning of the energy balance structure should take into consideration the current trends in electricity demand and the structure of coverage of this demand, the type and size of the energy infrastructure, access to specific energy carriers and costs of their acquisition, as well as the legal and environmental conditions (Michlak \& Nawrocki, 2015).

In addition to identifying and considering the above-mentioned conditions, their prioritization in the planning process is also important, which will decide the direction of national energy development for many years to come. On the one hand, we have a choice of priority of the energy security as regards which focus should be on the available national energy sources, regardless of their economy or adverse environmental effect, and, on the other hand, the environmental priority, in which lack own energy carriers in favor of imported raw materials less harmful to the environment is possible. The priority in the process of shaping the energy policy may also be minimizing the costs of electricity production, which frequently moves the environmental and energy security objectives into the background (Bluszcz, 2016). For this reason, balancing the objectives of the energy policy in practice is a very difficult task to implement and depends not only on economic decisions (Kowalska-Styczeń \& Sznajd-Weron, 2016), but also on a number of objective circumstances, such as the availability and sufficiency of energy sources, the price of energy carriers or the provisions of law. It is also worth mentioning that social factors, including the perception and the level of social acceptance for individual energy carriers, play a major role in shaping the energy policy, which often render impossible, in part or in whole, the realization of the assumptions of national energy strategies (Spałek, 2014).
In the Polish economy, hard coal has been the dominant energy carrier for many years. Poland also remains one of the world's ten largest hard coal producers (Burchart-Korol et al., 2016). Nonetheless, the Polish hard coal mining industry has been struggling with serious financial problems since the beginning of economic transformation (Sierpińska \& Bąk, 2013; Olkuski, 2013) and is still undergoing a profound repair restructuring (JonekKowalska, 2015; Karbownik \& Bijańska, 2000), particularly intensive in the last five years (Bąk, 2007). One of the main causes of the systematic financial collapse and the liquidation of mining production in Poland is the European Union's anti-coal policy forcing the diversification of energy sources and a significant increase in the share of renewable raw materials in the national energy balances. Therefore, the author of this article attempts to assess the validity of such a thesis, considering initially the changes in the energy balance as one of the many sources of risk for the Polish mining production (Bijańska \& Wodarski, 2014; Brodny et al., 2017).

Bearing in mind the above arguments, the main aim of this article is to carry out a long-term analysis of Poland's energy balance in the context of current and future conditions of the European climate policy and the sources of risk generated by the changes observed for Polish mining production. In order to accomplish this task, the following were conducted during the research: the identification and analysis of changes in Poland's energy balance in 1965-2015, the assessment of risk related to the change of the share of individual energy carriers in the energy balance and the assessment of the financial results of the Polish hard coal mining industry in the context of identified changes in the energy balance.

\section{Methodology}

The research part of this article is divided into two subsections, for which the research methodology was individually adjusted. The first one concerns the longterm analysis of changes in the energy balance and uses statistical data on the 
consumption of individual energy carriers in Poland in 1965-2015. This analysis refers to renewable and non-renewable resources using the trend functions adjusted to data and using the mediumterm rate of changes to assess the intensity of research processes

$$
T_{n}=\left(i_{g}-1\right) \times 100 \%
$$

where:

$$
i_{g}=\sqrt[n-1]{i n / n-1_{n-1 / n-2} \times i_{2} / 1}
$$

$i$ - chain dynamics index,

$n$ - the number of observations.

The second subsection refers to the risk identification and assessment that was carried out using typical measures of variation in the form of the standard deviation (3) and the coefficient of variation (4):

where:

$$
s=\sqrt{\frac{\sum_{i=1}^{n}(x-\bar{x})^{2}}{n-1}}
$$

$\bar{x}$ - the arithmetic mean,

$x$ - another variable in the sample,

$n$ - the number of observations in the sample.

$$
v=\frac{s}{\bar{x}} \times 100 \%
$$

where:

$$
\begin{aligned}
& \bar{x} \text { - the arithmetic mean, } \\
& s \text { - the standard deviation. }
\end{aligned}
$$

In addition, the Pearson correlation coefficient for assessing the linear correlation strength (5) between the analyzed variables was used to assess the relations between the electricity consumption and the hard coal share in Poland's energy balance and the results of the Polish hard coal mining industry.

$$
r_{x y}=\frac{\operatorname{cov}(x, y)}{s_{x} \times s_{y}}
$$

where:

$\operatorname{cov}(x, y)$ - the covariance of $\mathrm{x}$ and $\mathrm{y}$ variables, $s_{x}, s_{y}-$ standard deviations of variables $\mathrm{x}$ and $\mathrm{y}$.

In addition to the quantitative risk assessment carried out using the above parameters in the context of Poland's energy balance, a descriptive analysis of the sources of risk in the Polish hard coal mining industry was presented in the 
research section, which was conducted using a risk checklist containing the most important factors affecting the functioning of the analyzed sector.

\section{Research Results}

\section{Structure of The Energy Balance in Poland And Its Changes}

In the structure of the Polish energy balance, hard coal has been dominating for many years, which is largely due to the availability and abundance of this raw material that is located in the Upper Silesian and Lublin Coal Basins (Chart 1). Nevertheless, over the past fifty years of analysis, the share of this raw material in primary energy consumption has systematically decreased from $88 \%$ in 1965 to $52 \%$ in 2015. Coal is being replaced by natural gas and crude oil. The share of natural gas is rising in the analyzed period from $3 \%$ to almost $16 \%$, and the share of crude oil is rising from $9 \%$ to over $26 \%$. Thus, the diversification of energy sources is observed primarily as regards non-renewable carriers. The share of renewable energy sources in the Polish energy balance is growing very slowly and, by 1997, it did not exceed 1\%. Among these sources, Poland uses mainly biomass, wind energy and hydropower. As a result, despite the changes noted, coal has remained a key energy resource in the Polish economy for many years.

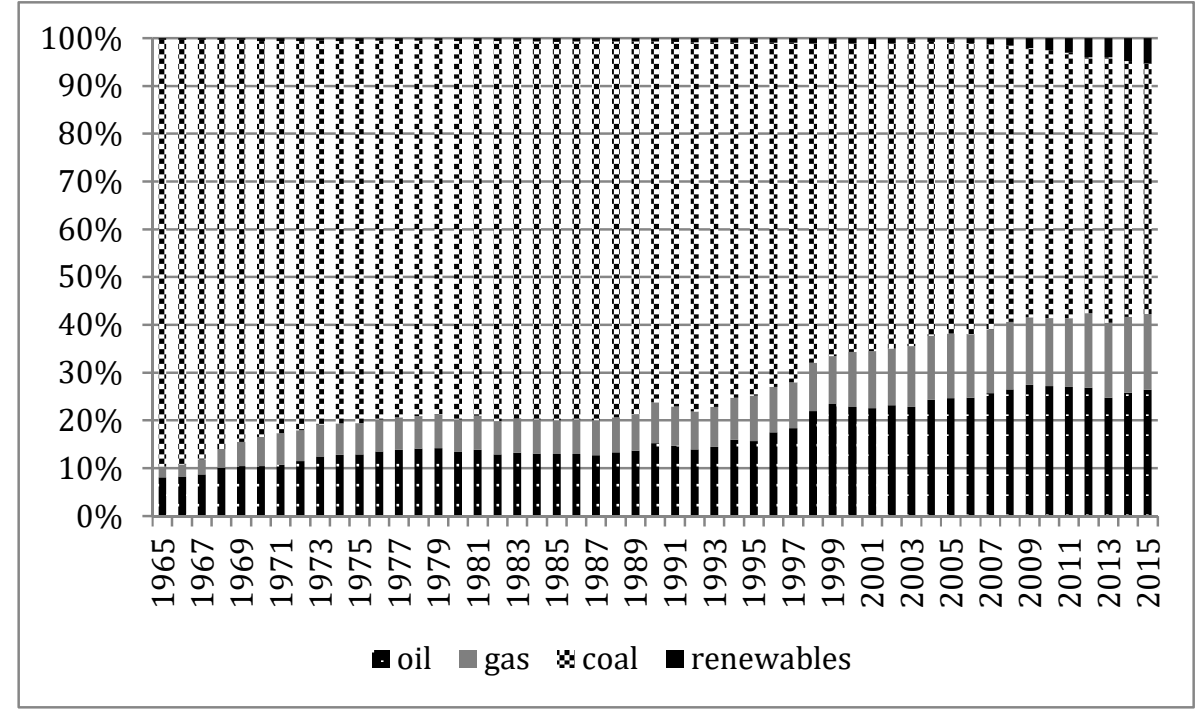

Chart 1: Structure of the energy balance in Poland in 1965-2015 [\%]

Source: own work on the basis of data of BP Statistical Review of World Energy 2016.

The reduction in the share of hard coal in the Polish energy balance is strongly correlated with the changes in total primary energy consumption (Chart 2), which was mainly accompanied by a decrease in hard coal consumption as the most important energy carrier. This is clearly confirmed by trend functions (quite well matched to actual data) illustrating the changes in energy and hard coal consumption in 1965-2015, in the form of a parabola of very similar values of polynomial coefficients. The greatest energy and hard coal consumption was therefore in 1975-1989, when the Polish economy was developing mainly due to energy-intensive heavy industry. Since 1990, after the economic and systemic transformation, the consumption of primary energy and hard coal has been steadily decreasing, as a result of changes in the structure of the Polish economy, including the liquidation of a significant part of heavy industry and the shift of economic activity towards less energyintensive industries as well as services and 
trade. The reduction in electricity consumption also increases the efficiency and efficacy of power plants and combined heating plants, achieved through the modernization and replacement of technical infrastructure into a more modern and innovative one (Kmieciak et al., 2012). The above conclusions also clearly confirm the reduction of the energyintensity of the Gross Domestic Product (GDP), which shows the change in the manner of Poland's economic development from extensive to intensive. These circumstances were not and are not conducive to the maintenance or growth of mining production, which was even more evident in 2001-2015, when electricity consumption was characterized by a slow upward trend, despite which the hard coal consumption continued to decline. During that period, hard coal was systematically replaced by crude oil and natural gas. It should be noted here that, despite less harmful impact on the environment, these raw materials - like hard coal - are not renewable. It is therefore difficult to say that a significant reduction in both consumption and hard coal share in Poland's energy balance is the result of only the European Union's anti-coal policy.

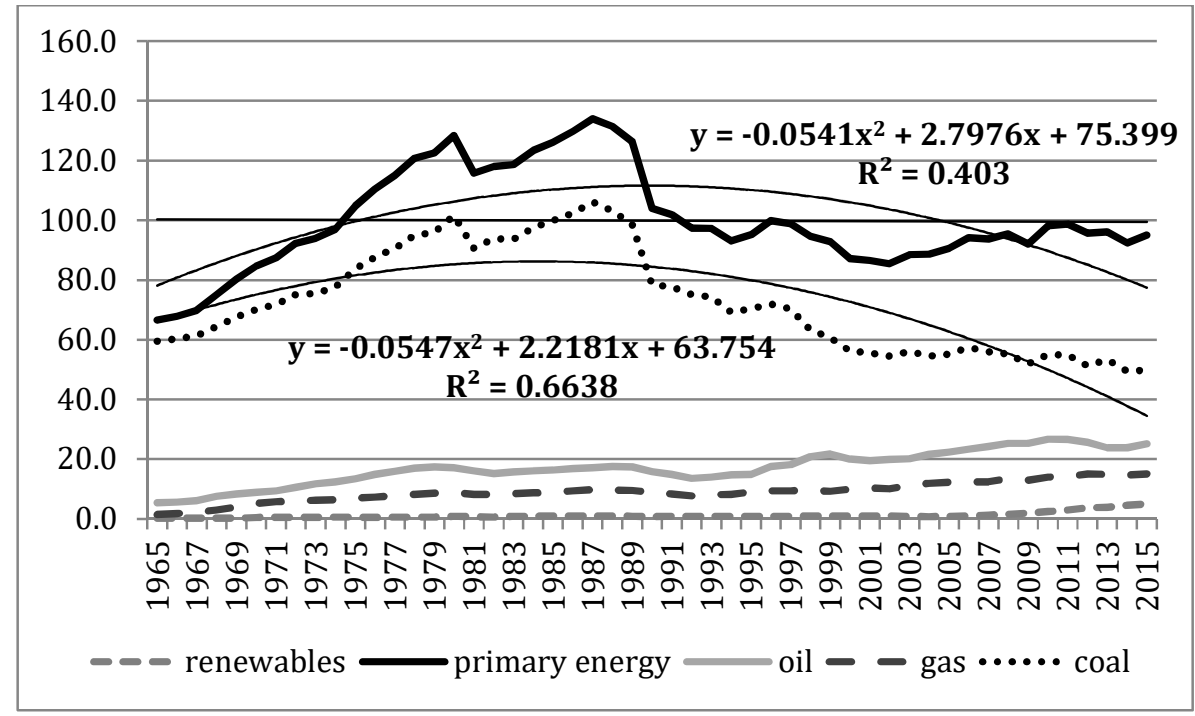

\section{Chart 2: Consumption of primary energy and non-renewable energy sources in Poland in} 1965-2015 [Mtoe]

Source: own work on the basis of data of BP Statistical Review of World Energy 2016.

The above argument also supports the very slow increase in the use of renewable resources (Chart 3) and their share in the Polish energy balance, which by 2003, in terms of value, did not exceed 1 Mtoe (compared to the total consumption of 88.5 Mtoe) and, in percentage terms, was not more than $1 \%$. It is only since 2005 that a significant increase in the use of renewable energy sources has been observed, whereby in 2015 their share in the structure of meeting the energy demand was slightly more than $5 \%$. Whereby, since 1965, the Polish economy has been using only hydropower and, to a very limited extent, wind energy from renewable resources. The increase in the latter has been observed since 2003, as has been the increase in the use of biomass as a new renewable energy source. 


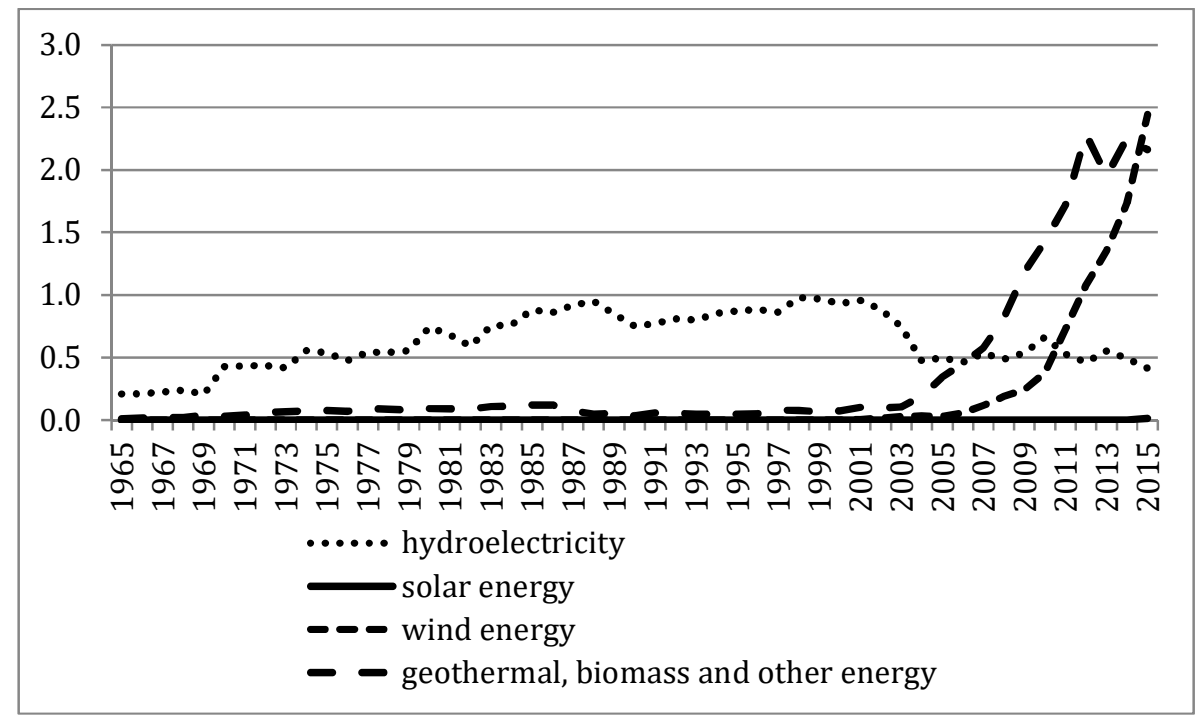

Chart 3: Consumption of renewable energy sources in Poland in 1965-2015 [Mtoe]

Source: own work on the basis of data of BP Statistical Review of World Energy 2016.

At this point, it is worth mentioning the objective limitations related to the possibilities of using renewable energy sources in Poland. Thus, the use of water energy would require significant investment outlays and long-term development of technical infrastructure. The development of hydropower sector is not an easy and short-term task. Poland due to geographical location and the resulting climatic conditions - cannot also use the potential of solar energy. It is also not rich in geothermal energy sources. In connection with the above, by 2017, primarily wind energy and energy from biomass combustion have been used from available renewable energy sources. In this respect, Poland has favorable geographic, climatic, and agricultural conditions, in the form of possibilities of growing energy crops, including willow, straw, poplar, and miscanthus. In addition, the wind energy development was supported by the investment subsidy system, which unfortunately was seriously reduced in 2016. The value of the so-called green certificates used to subsidize the production of wind energy was significantly reduced. New more stringent regulations on wind power plants have been introduced, which state that such a facility should be located at a distance of at least ten times the height of the wind turbine (i.e. about $1.5-2 \mathrm{~km}$ ) from the buildings, which significantly hinders and increases the development costs of infrastructure. In addition, since 2017, wind farms will not be able to sell energy at a regulated price that will adversely affect their financial results and the development of the entire industry, as more than half of wind power companies suffered financial losses in 2016.

\section{Energy balance and sources of risk for Polish mining production}

In the light of the above, it can be stated that the changes in Poland's energy balance, including the decrease in the use and share of hard coal in total electricity production, pose a threat for the possibility of selling this raw material by Polish mining enterprises. Limiting the possibilities of selling negatively affects the revenue side of the financial result and it is a source of market risk for entities operating in the Polish coal mining industry. Nevertheless, the changes observed are evolutionary in nature and allow for the adaptation to changing market conditions. This is confirmed by the risk intensity assessment in the form of 
Table 1: Measures of risk of mining production in Poland

\begin{tabular}{|l|c|c|c|}
\hline \multicolumn{1}{|c|}{ Specification } & $\begin{array}{c}\text { Arithmetic } \\
\text { mean }\end{array}$ & $\begin{array}{c}\text { Standard } \\
\text { deviation }\end{array}$ & $\begin{array}{c}\text { Coefficient of } \\
\text { variation }\end{array}$ \\
\hline Primary energy [Mtoe] & 99.9 & 16.7 & $17 \%$ \\
\hline Crude oil [Mtoe] & 17.1 & 5.6 & $33 \%$ \\
\hline Natural gas [Mtoe] & 9.1 & 3.3 & $37 \%$ \\
\hline Coal [Mtoe] & 72.6 & 17.4 & $24 \%$ \\
\hline Hydropower [Mtoe] & 0.6 & 0.2 & $36 \%$ \\
\hline Solar energy [Mtoe] & 0.0003 & 0.0018 & $612 \%$ \\
\hline Wind energy [Mtoe] & 0.2 & 0.5 & $288 \%$ \\
\hline $\begin{array}{l}\text { Geothermal energy, biomass, and other } \\
\text { renewable resources [Mtoe] }\end{array}$ & 0.4 & 0.6 & $181 \%$ \\
\hline
\end{tabular}

Source: own work.

According to the data presented in Table 1, electricity consumption in Poland in the over 50-year analysis period was characterized by low variation expressed in the form of a coefficient of variation of $17 \%$. As regards raw materials with the highest share in the energy balance, it was crude oil and natural gas, whose share and use increased steadily, that were characterized by the average level of risk. The variability of hard coal consumption can also be found average. Renewable resources - except for hydropower - are characterized by high variability in time, which is the result of the low value of their use, increasing several times in recent years of the conducted analysis. It can therefore be stated that the intensity of risk related to pushing hard coal out of the energy balance is at an average level and does not constitute a sudden and violent threat to the functioning of mining enterprises in Poland. This is also confirmed by the annual average rate of change presented in Table 2 , which is about 3-5\% per year for non-renewable energy sources substituting coal. In turn, the annual average hard coal consumption itself decreases only by $0.36 \%$.

Table 2: Average annual rate of changes in Poland's energy balance in 1965-2015

\begin{tabular}{|l|c|}
\hline \multicolumn{1}{|c|}{ Specification } & $\begin{array}{c}\text { Average annual rate of changes } \\
{[\%]}\end{array}$ \\
\hline Primary energy & $0.71 \%$ \\
\hline Crude oil & $3.12 \%$ \\
\hline Natural gas & $4.76 \%$ \\
\hline Coal & $-0.36 \%$ \\
\hline Hydropower & $1.39 \%$ \\
\hline Solar energy & $310.88 \%$ \\
\hline Wind energy & $61.20 \%$ \\
\hline Geothermal energy, biomass, and other renewable resources & $11.17 \%$ \\
\hline
\end{tabular}

Source: own work.

Given that the risk is analyzed and assessed in the context of deviations from the assumed financial result, it is worth looking closer at the results of the Polish hard coal mining industry (Chart 3). Hence, the Polish hard coal mining industry was profitable only in the years 2003-2005 and 2010-2012. In other periods, it was a lossmaking industry. Taking into account the systematic downward trend in hard coal consumption observed since the beginning of the 1990s, it is hard to see the reasons

Izabela Jonek-Kowalska (2019), Journal of Eastern Europe Research in Business and Economics, DOI: 10.5171/2019.334489 
for the improvement of the financial result in increasing the volume of sales. Thus, in 2003-2005, positive financial results followed from effective restructuring and reduction of mining production costs (Gumiński et al., 2008) and, in 2010-2012, the increase in revenues corresponded to an increase in the price of hard coal on the world and domestic markets. It is worth pointing out that Polish hard coal is characterized by low price competitiveness resulting - especially in recent years - from high and ever-increasing unit production costs, which, together with the deteriorating quality, are the main cause of problems with the sale of this raw material.

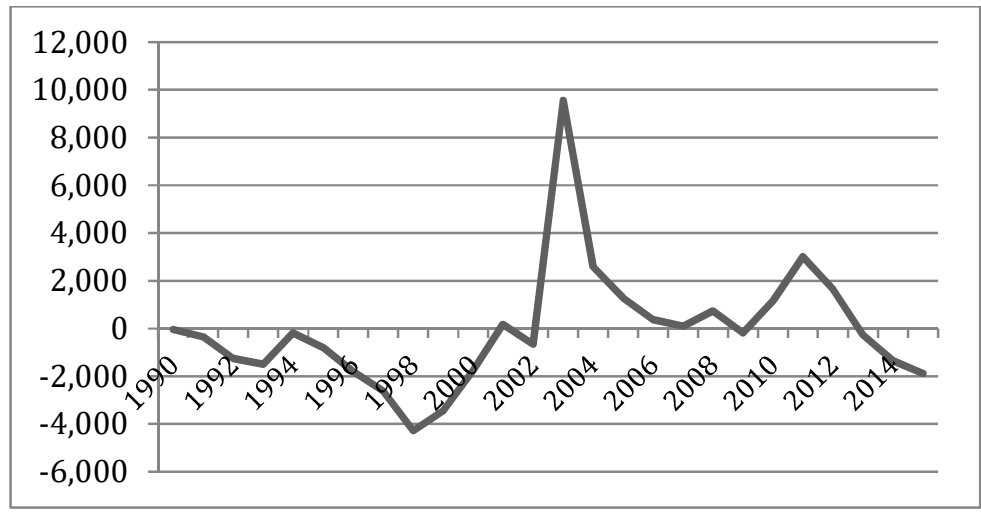

Chart 3: Financial result of the Polish hard coal mining industry in 1990-2015 [in PLN mln]

Source: own work on the basis of data from the Ministry of Energy.

1 The financial result statistics are available from the post-transformation period, hence the limited research period.

Izabela Jonek-Kowalska (2019), Journal of Eastern Europe Research in Business and Economics, DOI: 10.5171/2019.334489 
The Pearson correlation coefficients were calculated to complete the analysis and assessment of the relations between the financial results of the Polish hard coal mining industry and the consumption of primary energy and its individual carriers. The calculation results are shown in Table 3.

Table 3: Pearson correlation coefficients for the relations between the financial results of the Polish hard coal mining industry and the consumption of primary energy and its carriers

\begin{tabular}{|c|c|}
\hline Specification & Correlation coefficient \\
\hline financial results - primary energy & -0.2183 \\
\hline financial results - crude oil & 0.2229 \\
\hline financial results - natural gas & 0.3056 \\
\hline financial results - renewable resources & -0.0104 \\
\hline
\end{tabular}

Source: own work.

According to the results in Table 3 , there are weak positive relations between financial results and the crude oil and gas consumption, but they are statistically insignificant, as are the two other negative relations between the results and the consumption of primary energy and renewable resources. It can therefore be concluded that no significant and linear relations between the results of mining production and the level of consumption of primary energy and its carriers have been observed.

\section{Checklist of Significant Sources of Risk in The Polish Hard Coal Mining Industry}

In the situation of evolutionary changes in Poland's energy balance, it is hard to recognize them as the main cause of the crisis in the mining industry and the decommissioning of a large part of unprofitable hard coal mines in 2016, especially that in 2008-2016 a record value of hard coal imports to Poland was recorded, which is confirmed by the existence of a significant and absorptive market for this raw material in the Polish power sector. At the end of research, it is worth to draw attention to the other sources of risk, which in recent years have accompanied and intensified their impact on the mining production in Poland. Thus, the significant sources of internal risk include:

- the growing unit cost of production (Magda, 2013; Gawlik,

\section{8; Gawlik \& Ksztelewicz,} 2005),

- a decrease in productivity,

- the lack of financial liquidity,

- the lack of funds for investments (Michalak \& Turek, 2012).

The first two sources of risk are the consequence of a significant decrease in production at less significant decrease in employment, which, with a high share of fixed costs, results in increased unit costs and lower overall productivity. What makes the situation worse is the high about 25\% - share of administrative workers, thus non-productive, in total employment. In turn, losses in mines result in a reduction in internal financing, which, together with the reluctance of investors to lend to indebted enterprises, results in a loss of financial liquidity. Moreover, the lack of financial resources negatively affects current and development investment opportunities, thus jeopardizing the further functioning of the entire sector.

External factors complicating the situation in the Polish extractive industry include:

- the fluctuations in coal prices on the international market with a high level of globalization of the raw materials market,

- the influx of cheaper hard coal from imports, 
- $\quad$ prohibition of financial support for the hard coal mining industry in the European Union.

Since 2008, Poland has been a net coal importer, which, taking into account its mining traditions, resource reserves, and production capacities, is remarkable. Nonetheless, imported coal - mainly from Russia and Kazakhstan - is cheaper and meets the requirements of Polish energy producers to a greater extent. The situation is further aggravated by fluctuations in the hard coal prices on the world market, which in the period of declines transfer very quickly to the globalized domestic market and contribute to deepening the losses of Polish mining enterprises. Meanwhile, the possibilities of financing a declining industry have been significantly reduced by the European Union's directive on banning public aid for the hard coal mining industry, leaving the possibility of subsidizing hard coal mines only in the event of their permanent decommissioning.

\section{Conclusion}

Summing up the considerations in this article, it must be stated that changes in Poland's energy balance are a source of risk for mining production, as they signify a reduction in the demand for hard coal, which limits the market for this raw material. Nevertheless, these changes are taking place slowly, which makes it possible for the mining enterprises to adapt to the changing economic environment and it should no longer present a threat to the further functioning of the sector, because even if the rate of reduction of coal consumption rises to $1 \%$ per year, this raw material will disappear from Poland's energy balance no sooner than in over 50 years. A serious threat, however, is the coupling of all the sources mentioned in the article, which when cumulated, intensely and permanently negatively affect both the revenue and cost side of the result, contributing to deepening the losses of Polish mining enterprises.

On the basis of the presented analysis, it can also be stated that in the Polish energy policy priority is given to energy security supporting maintaining coal as a leading energy raw material due to its national availability. It is also accompanied by a social priority in the form of a postulate of maintaining jobs in the region and the economy. Now and in the future, however, it can significantly impede the implementation of environmental priorities resulting from the European Union regulations, since Poland will find it difficult to achieve almost $20 \%$ share of renewable raw materials in the energy balance by 2020 . It will also be impossible to realize the economic priorities, due to the lack of price competitiveness of the Polish raw material and the high costs of its acquisition. In such circumstances, it seems reasonable to try to balance the presented priorities by improving the price competitiveness of Polish mining production and to take greater account of renewable energy sources in energy policy, which will allow all raw materials' markets to be equally and rationally developed.

\section{Acknowledgment}

This article was funded by statutory research of the Faculty of Organization and Management of the Silesian University of Technology no. BK-211/ROZ0/2017 (13/990/BK_17/0088).

\section{References}

1. Bąk, P. (2007), 'Characteristic of the capital gaining sources and financing the activity of coal mine enterprises. Part 1: Sources of the own capital', Mineral Resources Management, 23, 93-108.

2. Bijańska, J. and Wodarski, K. (2014), 'Risk management in the planning of development projects in the industrial enterprises. Three-level mass-transfer model for the heterogeneous polymerization of olefins', Metalurgija, 53, 276-278.

3. Bluszcz, A. (2016), 'European economies in terms of energy dependence', Quality and Quantity 5, 1531-1548.

4. Brodny, J., Alszer, S., Krystek, J. and Tutak M. (2017), 'Availability analysis of selected mining machinery', Archive of Control Science 27, 197-209. 
5. Burchart-Korol, D., Fugiel, A., Czaplicka-Kolarz, K. and Turek M., 'Model of environmental life cycle assessment for coal mining operations', Science of The Total Environment 562, 61-72.

6. Gawlik, L. (2008), 'Budowa i weryfikacja modelu ekonometrycznego dla określenia liniowej zależności pomiędzy kosztami wydobycia a wielkością wydobycia', Mineral Resources Management 24, 27-44.

7. Gawlik, L. and Kasztelewicz, Z. (2005), 'Zależność kosztów produkcji węgla w kopalni węgla brunatnego „Konin” od poziomu jego sprzedaży', Prace Naukowe Instytutu Górnictwa Politechniki Wrocławskiej 112, 231- 242.

8. Gumiński A., Karbownik A., Wodarski K. and Jędrychowski S. (2008), 'Restrukturyzacja zatrudnienia w polskim górnictwie węgla kamiennego w latach 1998-2006', Wiadomości Górnicze 59, 166174.

9. Jonek-Kowalska I. (2015), 'Challenges for long-term industry restructuring in the Upper Silesian Coal Basin What has Polish coal mining achieved and failed from a twenty-year perspective?', Resources Policy 44, 135-149.

10. Karbownik A. and Bijańska J. (2000), Restrukturyzacja polskiego górnictwa węgla kamiennego w latach 1990-1999. Politechnika Śląska, Gliwice.

11. Kmieciak R., Michna A. and Męczyńska A. (2012), 'Innovativeness, empowerment and IT capability: evidence from SMEs', Industrial Management and Data Systems 112, 707-728.

12. Kowalska-Styczeń A. and SznajdWeron K., 'From consumer decision to market share - unanimity of majority?', JASSS Journal of Artificial Societies and Social Simulation 19, 1-13.
13. Magda, R. (2013), ‘Ocena wpływu ograniczenia stopnia wykorzystania zdolności produkcyjnej w ścianach wydobywczych na jednostkowy koszt własny', Przegląd Górniczy, 9, 110-113.

14. Michalak, A. and Turek, M. (2012), 'A method of pricing an asset lost in a mining catastrophe', Archives of Mining Sciences 57, 799-814.

15. Michlak A. and Nawrocki T. L. (2015), 'Comparative analysis of the cost of equity of hard coal mining enterprises - an international perspective', Mineral Resources Management 31, 49-72.

16. Nawrocki T. and Jonek-Kowalska I. (2016), 'Assessing operational risk in coal mining enterprises - internal, industrial and international perspectives', Resources Policy 48, 50-67.

17. Olkuski T. (2013), 'Zależność Polski w zakresie importu węgla kamiennego', Mineral Resources Policy 29, 141-155.

18. Sierpińska M. and Bąk P. (2013), 'The role of corporate bonds in financing mining sector companies during an economic downturn', Mineral Resources Policy 29, 141-155.

19. Spałek S. (2014), 'The influence of country of origin on project management: an international empirical study', Proceedings of 19th International Scientific Conference on Economics and Management 2014. ICEM 2014, 23-25 April 2014, Riga, Latvia. Ed. by: E. Gimzauskiene. Amsterdam: Elsevier Science, 4-7.

20. Turek M. (2015), 'Technicalorganizational aspects of underground coal gasification in an active coal mine on an example of experiment carried out in Wieczorek coal mine', Przemysł Chemiczny 94, 1012-1017. 